\title{
Using force: experiences of Belgian police officers
}

That is the difficult part of our job. Our job is not black or white; it is grey. We are constantly in a grey zone, and in one snap you have to say 'Okay, now I have to do this or that...' (RO7)

The police are authorized to use force in order to protect the fundamental rights and freedoms of citizens. Since this authorization implies that they are also expected to respect these values and basic human rights while performing their police function, the use of force is not a black-and-white issue. Although there has been plenty of academic attention given to the factors that determine proper use of force by the police, most research in this field is based on police experiences abroad (such as in the US). The aim of this article is to gain insight into the type of force that is most frequently used by Belgian police officers in their daily activities, and to examine the individual and contextual triggers that result in using force. First, the results of an online survey of police officers in three local police zones are presented. Second, qualitative data are used to gain more insight into the factors, individual as well as contextual, that influence the decision to use force. Results show that, according to Belgian police officers, individual and contextual aspects determine the use of force. The authors conclude that police officers should be provided not only with training on typical situations, but also with training to handle unpredictable cases, as well as individual coaching and aftercare. Increased transparency and reporting of the use of force and evolutions thereof could provide basic information to develop training, coaching and aftercare.

Keywords: police, use of force, decision making, interviews, survey

\section{Introduction}

The police are allowed the use of force in our democratic societies, in exchange for the protection of our democratic values and basic human rights. The legal authorization to make use of force brings with it an expectation that the police respect these values and basic human rights when using force (Goossens, 2006; Jones et al., 1996). This is not straightforward in practice; as an inherent part of their policing function, police officers may suddenly find themselves in unexpected situations in which they have to make split-second decisions on how to react and whether or not to use force (Bourdoux and Cuvelier, 2007; Terrill, 2014; Timmer, 2005). The legitimate use of force is a way to maintain order, to enforce the law and to ensure safety (Terrill, 2014). This is addressed in the work of Bittner (1974), who states that the reason that the public calls the police is that something has to be done about a situation right now. Some types of emergencies calling for quick action are those which call for the use of force. As such, the use of force is inherent in the policing function (Bittner, 1980; Brodeur, 2010). More explicitly put: we expect the police to use force. The question, then, is not whether the police apply force, but how they apply it (Terrill, 2014). The use of force, Terrill argues, 'is restricted to lawful purposes' (2014, p. 269). The legitimate use of force is more than a simple legal determination; it is a judgmental dilemma that implicates the moral ambiguity of the use 
of coercive authority (Dick, 2005). Terrill (2014) sketches a continuum, ranging from legally legitimate reasons for use of force to unlawful, illegitimate reasons. The latter is the use of force that 'crosses the line', or that can be classified as police brutality. This paper will not focus on police brutality, as its aim is to study police use of force as a continuum, with verbal force at one end, and the use of a firearm at the other. The intent of this analysis is to gain insight into the types of force that are most frequently used by police officers, and to examine the individual and contextual triggers that result in applying force.

Although there has been plenty of academic attention paid to this topic, most research in this field is based on experiences of police outside continental Europe (such as in the US). Naturally, the context in which US police officers operate can be expected to differ largely from the Belgian context. For example, US police officers will most likely take into account that a high percentage of US citizens own one or more guns (36\% in 1999) (Cook et al., 2011), a situation that is completely different from the Belgian context [1]. Another factor of impact is the policing style that is observed by policy. Examples of policy influences include the community oriented policing style in Belgium, in which police are expected to make use of a broad array of potential response methods in addition to the use of force; the tendency of police officers to carry weapons in the line of duty (or not, as is the case in the UK and Norway) and the actual use of weapons; in other words, whether it is 'tradition' to use a firearm or not. For example, Norwegian police officers only fired guns twice in 2014, and did not actually wound anyone [2]. This indicates that in comparison with the US, a very different stance is taken on the use of firearms by the police of different nations.

Other examples of influences on the use of force are the 'general relationship between the police and the citizens they police [...], domestic laws and customs that define acceptable and unacceptable police practices' (Stenning et al., 2009). In short, studying police use of force in other than AngloSaxon countries is essential as there is potential for bias in the literature when assessing the elements police officers take into account when they decide to use force. Results of those studies may be difficult to transfer to other national contexts. This article focuses on Belgian research, and consequently takes into account the community oriented policing policy of this country, and the fact that Belgian police officers are permitted to carry a firearm during their daily activities. In this article, the use of force will be mapped as a first attempt to fill the void of official use-of-force statistics. First, the types of force that police officers are legally permitted to use are discussed, with a focus on the factors involved in split-second decisions to apply force in daily situations. Second, the authors inspect the individual and contextual triggers for the use of force as reported by Belgian police officers. These two goals are met by means of both quantitative (survey) and qualitative (interviews) methods.

\section{The Belgian police organization and the use of force}

In Belgium, one integrated police organization is structured at two levels: the federal level and the local level. Legally speaking, the use of force is considered one of the means of coercion that police officers can avail themselves to, in addition to identity controls, body searches and handcuffing (Goossens and Hutsebaut, 2007). Police officers are only allowed to use coercion (including the use of firearms) under certain conditions prescribed by law ${ }^{1}$. Police officers may use force when they are pursuing a legal goal which cannot be achieved in another, non-violent way. The use of force must be

\footnotetext{
${ }^{1}$ Law regarding police duties (B.S. August 5, 1992), article 1.
} 
reasonable and in proportion to the legal objective, and must be preceded by a warning, unless the warning renders their action ineffective ${ }^{2}$. The weapons each police officer has at his or her disposal are: a firearm; a straight, extendable baton and neutralizing instruments (pepper spray). The use of a firearm must always be preceded by a warning, unless it makes the action ineffective ${ }^{3}$. During education and training, police officers are taught to use force in correspondence with 'the pyramid of force'. This pyramid consists of the adjustment of the police officer's reaction to the opponent's behaviour (principle of proportionality) and the gradual increase or decrease of the level of force, ranging from non-physical means of coercion (e.g., summoning), to physical coercion without a weapon (e.g., pushing, pulling, punching, etc.), to the use of a weapon (e.g., baton, pepper spray or firearm) (Dejonghe, 2009). Although official guidelines prescribe that each application of force, with or without the use of a weapon, must be reported, official statistics on police use of force are unreliable, as these reports are not registered in a consistent and uniform manner. Data are scattered over 189 local police zones and 14 federal police departments, all of which have their own practices for reporting and registering the use of force[3].

\section{Triggers for the use of force}

Officers on the street make decisions regarding when to use force and how much to use on the basis of a number of factors, including the unique circumstances of the event at hand (Terrill, 2014). Some research associates the use of force with the individual characteristics of the police officer or of the citizen or suspect involved. It appears that male police officers (Alpert and Dunham, 2004; Bazley et al., 2007; Crawford and Burns, 2008; Garner et al., 1996; Kop and Euwema, 2001), officers with less formal education (Paoline and Terrill, 2007) and less experienced officers (Manzoni and Eisner, 2006; Paoline and Terrill, 2007) are more likely to use verbal or physical force. However, these individual characteristics appear to be only weak indicators of the use of force (Alpert and Mac Donald, 2001).

Other researchers state that the use of force is impacted by situational factors. Research shows, for instance, that the use of force is more likely when the suspect is under the influence of alcohol or drugs, or when the suspect is mentally ill (Engel et al., 2000). Other situational factors that are often mentioned in literature are: citizen compliance (Alpert and Dunham, 2004; Alpert et al., 2004; Terrill and Mastrofski, 2002), citizen demeanour (Engel et al., 2000; Klinger, 1994), the time and place of the intervention (Crawford and Burns, 2008), the number of police officers at the scene (Worden, 1996; Garner et al., 1996; Terrill and Mastrofski, 2002) and the number of bystanders (Crawford and Burns, 2008). These factors are said to be potential predictors of forceful action.

Still other studies indicate that organizational factors, such as the way agencies collect and use data on use of force or the characteristics of the location of the police force (Alpert and Mac Donald, 2001; Terrill and Reisig, 2003) can affect police use of force. The informal structure of the police organization, the organizational philosophy (Terrill and Mastrofski, 2002) and the local police culture (Chan, 1996; Herbert, 1998; Paoline, 2003; Van Maanen, 1974) also have an impact. Terrill et al. (2003), for instance, establishes that the extent to which police officers are committed to the traditional police culture may translate into observed differences in coercive behaviour.

\footnotetext{
${ }^{2}$ Article 37

${ }^{3}$ Article 38
} 
A fourth category of research focuses on the emotional, psychological and physical reactions police officers experience during and after a dangerous intervention. Acute stress caused by (lifethreatening) danger can result in reduced visual and cognitive reaction times; temporarily diminished senses of hearing and sight (also known as tunnel vision) and deteriorated oral, social and fine motor skills (Eysenck et al., 2007; Grossman and Christensen, 2004; Klinger, 2006; Nieuwenhuys and Oudejans, 2010; Novy, 2012; Shipley and Baranski, 2002; Siddle, 1995; Taverniers et al., 2011; Vonck, 2007). The weight of body armour and the frequency of exercise may also affect police officers' cognitive function (Roberts and Cole, 2013).

The majority of the aforementioned studies are based on observational data, survey data or official records on the use of force. In the majority of these studies, quantitative analyses are used to examine correlates of the use of force (Noppe, 2015). Only a few studies (Birkbeck and Gabaldon, 1996; Holmes et al., 1998; Klinger and Brunson, 2009; Stenning et al., 2009) asked police officers how they perceive use-of-force incidents and which factors they feel justify higher levels of force. In this article, quantitative data drawn from a survey and qualitative data collected from interviews are combined to gain insight into both the occurrence of the use of force by Belgian police officers and the perceived triggers for the use of force.

\section{Methodology}

As stated, data from two studies on the use of force by Belgian police officers are used. First, the results of an online survey of police officers in three local police zones are presented. Next, qualitative data are used to gain more insight into factors, both individual and contextual, that influence the use of force.

\subsection{Online survey $(N=197)$}

The first dataset consists of data from an online survey the authors conducted between November 2014 and February 2015 in three local police zones of Belgian cities [5]. The three local zones [5] were selected based on their involvement in this study from an early phase and their willingness to cooperate with the survey. In the first two police zones, all operational police officers involved in patrol work were invited to complete the questionnaire. In the third zone (LP3), the web link was spread amongst all operational police officers doing patrol, detective or district work. All police officers participated voluntarily. Confidentiality was guaranteed to encourage a high response rate. In total, 197 local police officers filled out the questionnaire, resulting in a response rate of about $37 \%$, which is not unreasonable for a survey on a highly sensitive topic such as this. However, the results are not representative of all Belgian police officers, nor of all police officers working in the three police zones.

Police officers were asked to indicate if they had ever used the following levels of force: verbal force (threats of the use of force), physical force, drawing a baton, striking with a baton, drawing pepper spray, using pepper spray, drawing a firearm, directing a firearm (not towards the subject), directing a firearm (towards the target), firing a warning shot or shooting. They were also asked to indicate the frequency of this behaviour during the previous 12 months ${ }^{4}$. By means of the software package SPSS,

\footnotetext{
${ }^{4}$ Never, only once, two times a year, quarterly, monthly, weekly or daily.
} 
descriptive analyses were conducted in order to gain insight into the types of force that are most frequently used by the police officers in their daily activities.

\subsection{Semi-structured interviews $(N=23)$}

In addition to gathering information on the use of force and the reasons for its use, a second study focused on understanding the subjective opinions and experiences of police officers. This was done by means of semi-directed interviews (Liedtka, 1992) with police officers at the local level in order to gain more in-depth insight into the triggers for the use of force, as perceived by the police officers.

Twenty-three police officers were interviewed by criminology students [6]. The respondents were selected on the basis of their daily tasks: they had to be doing patrol work (or had been doing patrol work [7] for a significant period of time). As with the previous study, a convenience sample was taken; the students were asked to contact the police zone of the city they lived in [8]. This resulted in a spectrum of police zones, including both large and small police zones. The topic list's design was influenced by earlier studies on the use of force. The length of the interviews varied from 30 minutes to 1.5 hours. The majority of the respondents volunteered for the interview, but in some cases respondents were appointed by their department chiefs.

During the interviews, respondents were asked about their opinion on the use of force, their experience in using force, the potential dilemmas they were confronted with and their perception of their position on a use-of-force continuum, which was assessed using the following question: Are you prone to using violence, or will you try to avoid it as much as possible and solve problems by talking?

Data was coded inductively using NVivo. A set of general codes was developed on the basis of the research questions, and further refined during the coding process (as in Grounded Theory, see van Staa and Evers, 2010). The overall interview data were analysed by both authors of this paper, who independently coded the interviews and then discussed the results. These results were cross-checked to increase validity (Weston et al., 2001). The coded phrases were then analysed by both authors, and reported in a first draft. These drafts were compared and discussed to ensure that both authors had the same understanding of coded fragments and concepts. The parts of the interviews related to opinions on the use of force, triggers for the use of force and the moral compass that police officers apply in their decision to use force or not are used for this article. These topics also reflect the majority of the responses.

Table 1 presents some background characteristics of our respondent group. As the table indicates, mainly male police officers were interviewed, and the study involved both young and more experienced police officers. 
Table 1: Respondents' background characteristics ( $N=23$ )

\begin{tabular}{|c|c|c|c|c|c|c|c|}
\hline $\mathrm{Nr}$ & Sex & \# years Police & \# years intervention & $\mathrm{Nr}$ & Sex & $\begin{array}{l}\text { \# years } \\
\text { Police }\end{array}$ & \# years intervention \\
\hline 1 & $M$ & 6 & 6 & 13 & $M$ & 7,5 & 7,5 \\
\hline 2 & $M$ & 18 & 18 & 14 & $M$ & \multicolumn{2}{|c|}{ Not specified (experienced police officer) } \\
\hline 3 & $\mathrm{M}$ & 14 & 14 & 15 & $\mathrm{M}$ & 0,5 & 0,5 \\
\hline 4 & $\mathrm{M}$ & 1,5 & 1,5 & 16 & $\mathrm{M}$ & 4 & 4 \\
\hline 5 & $M$ & 11 & 11 & 17 & $\mathrm{M}$ & 25,5 & 8 (+ in the first yrs of career) \\
\hline 6 & $M$ & 5 & 5 & 18 & $\mathrm{~V}$ & 18 & 11 \\
\hline 7 & $\mathrm{M}$ & 3 & 3 & 19 & $\mathrm{M}$ & 2,5 & 2,5 \\
\hline 8 & $M$ & 25 & 15 & 20 & V & 21 & 6 \\
\hline 9 & $\mathrm{M}$ & 16 & 16 & 21 & $M$ & 29 & 13 (+in the first yrs of career) \\
\hline 10 & $M$ & 8 & 6 & 22 & $\mathrm{~V}$ & 4 & 4 \\
\hline 11 & $\mathrm{M}$ & 20 & 3 to 4 & 23 & $\mathrm{M}$ & 3 & 3 \\
\hline 12 & $M$ & 2,5 & 2,5 & & & & \\
\hline
\end{tabular}

\section{Results}

\subsection{The use of force in three local police zones: statistics}

The survey data and the interview results give us a first look into self-reported use of force by Belgian police officers.

Figure 1: The use of force: Did you use ... at least once in your career? $(\mathrm{N}=197)^{5}$

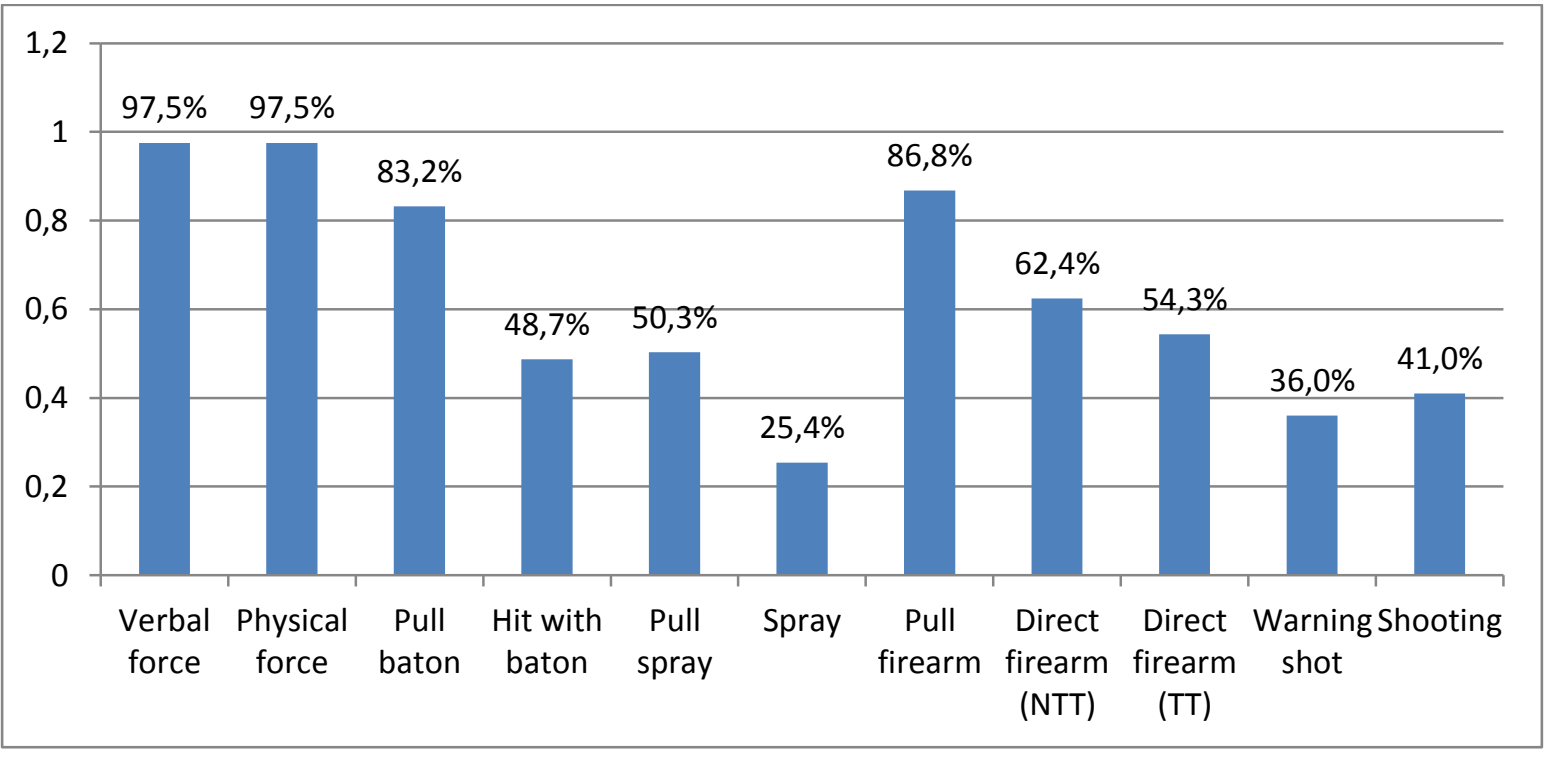

Figure 1 clearly illustrates that almost all officers had used verbal and physical force at least once in their careers. A large percentage of the police officers had also drawn their baton or firearm $(83.2 \%$ and $86.8 \%$, respectively), as contrasted to pepper spray, which had only been drawn by half of the police officers. There was also a higher frequency of police officers who had used their batons (48.7\%) in comparison to using pepper spray (25.4\%). Also, many police officers had drawn their firearm and pointed it, either not towards the target or towards the target $162.4 \%$ and $54.3 \%$, respectively). Only a few police officers had actually used a warning shot or fired towards the target at least once in their career (3.6\% and $4.1 \%$, respectively).

\footnotetext{
${ }^{5}$ NTT means 'not towards the target' TT means 'towards the target.'
} 
Figure 2: Use of force: frequency in the last 12 months $(\mathrm{N}=197)^{6}$

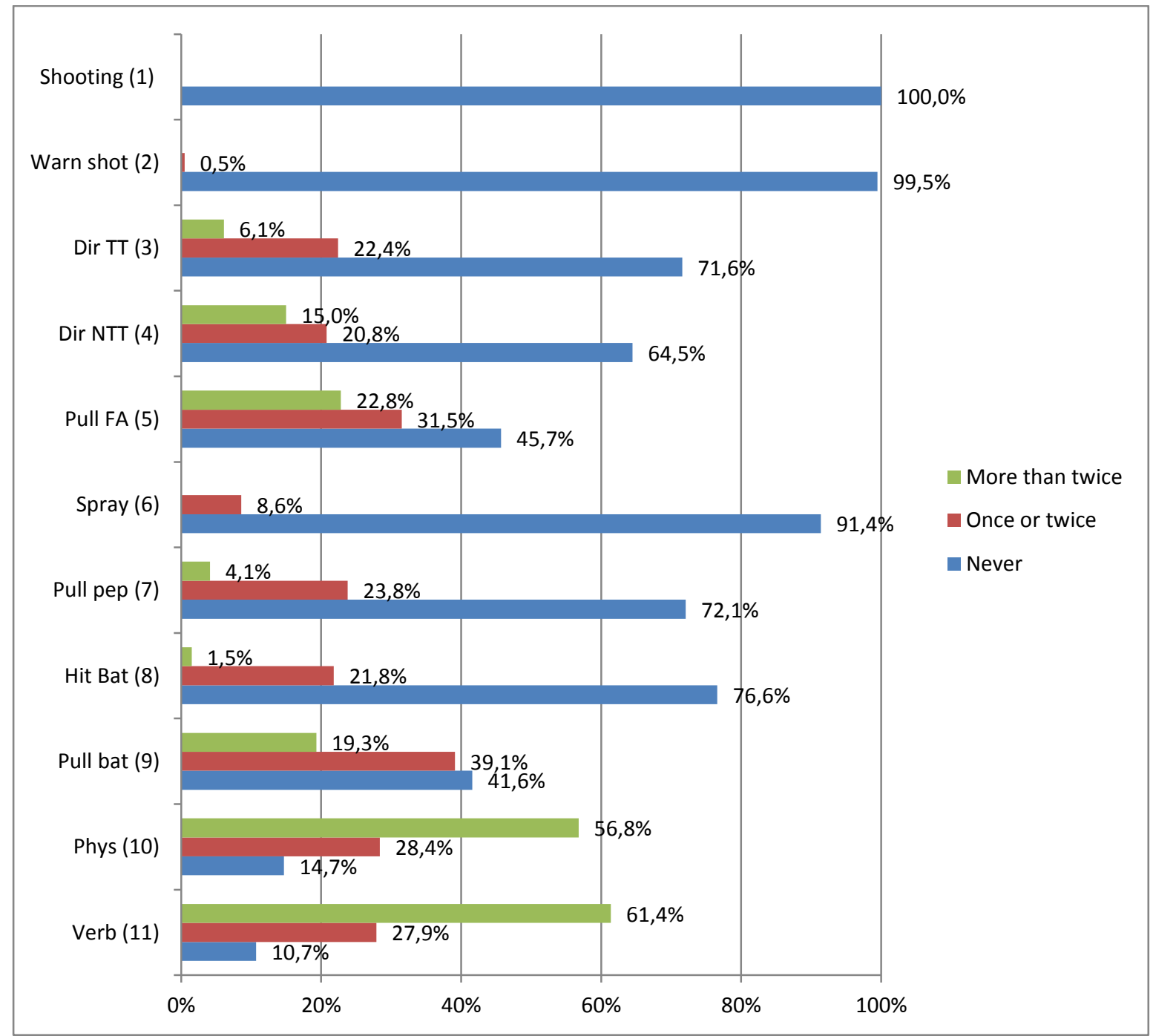

As shown in Figure 2, verbal (89.3\%) and physical (85.2\%) force had been used the most in the previous 12 months. About $60 \%$ of the police officers had used verbal force more than twice a year, and $56.8 \%$ of the police officers had used physical force more than twice a year. Striking with the baton, drawing the pepper spray and using the pepper spray had occurred infrequently $(1.5 \%, 4.6 \%$ and $0 \%$ had used it more than twice a year, respectively), while almost $20 \%$ of the police officers had drawn their baton more than twice in a year. Likewise, about $20 \%$ of the police officers had drawn their firearm more than twice in a year, but only one police officer had fired a warning shot. Nobody in the previous year had fired towards a target.

Figures 1 and 2 illustrate that police officers do not frequently use their weapons (hitting with the baton, spraying or shooting), but do frequently draw their weapons. Figure 2 shows that $58.4 \%$ had drawn their baton, $27.9 \%$ had drawn their pepper spray and $54.3 \%$ had drawn their firearm at least

${ }^{6}(1)$ shooting towards the target; (2) firing a warning shot; (3) directing the firearm towards the target; (4) directing the firearm not towards the target; (5) pulling the firearm; (6) spraying with the pepper spray; (7) pulling the pepper spray; (8) hitting with the baton; (9) pulling the baton; (10) using physical force; (11) using verbal force. 
once in the previous 12 months. More than one-fifth of the police officers had pulled their firearm quarterly, monthly or weekly.

\subsection{Findings from the interviews of Belgian police officers}

\subsubsection{Opinions on the use of force}

In the interviews, police officers indicated that physical, unarmed force seem to be used on a regular basis:

I will not say that it happens weekly, but no month goes by without [someone] having used physical force. (R13)

Specifically, respondents referred to the kind of pushing and pulling sometimes necessary to get an individual outside or onto the ground.

Most respondents indicated a clear preference for the baton, the pepper spray or physical force without a weapon. Such preference is mainly prompted by the individual level of training, with some influence from personal preference.

Some people are maybe more likely to reach for the baton, because they are less trained. Besides the police training, I am doing fighting sports, and yes, I know I am a little bit more skilled with my hands to get someone on the ground. (R06)

Furthermore, the interviews made clear that drawing the firearm is a standard procedure during searches in cases of burglary or robbery, which explains the frequency of use.

\subsubsection{Triggers for the use of force}

When discussing the use of force, almost all respondents referred spontaneously to the 'pyramid of force'. The respondents stated that it is important to start as low as possible on the force scale (principle of subsidiarity), implying the possibility to increase one or more levels when necessary. Once one has opted for a higher level of force, it is very difficult to return to a lower level.

You hold that gun at that time, so you cannot do anything else; you're on a whole other level and you cannot go any higher, so either he listens, or ... You cannot put your gun back and take another weapon. (R07)

Some respondents, however, stated that in cases of life-threatening danger (for instance, when threatened with a knife or a firearm), the pyramid of force no longer applies.

Look, personally, when I am threatened with a knife, I immediately take my gun... As in most cases, when the opponent is in front of you-[...] There have been experiments; if that opponent is seven meters away from you and suddenly moves, then you will never be quick enough. Even when your weapon is still in the holster, you can never be quick enough to pull your weapon to neutralize him. (R01)

There seems to be no optimal or fixed way to intervene in a dangerous situation. One respondent explained that it really depends on the type of situation; in one case it might be better to first talk 
with the person(s) involved, but in other cases the situation has to be cooled down right away, and there is no time for conversation.

One of the respondents referred to an intervention for an armed person who tried to provoke 'a suicide by cop' [9] in public. The man was standing on the street with a gun in his hands. At first, he was only swaying around with it, but at a certain moment he started to point the gun towards a target.

Then you constantly, constantly, constantly make the assessment: will I do it or will I not do it? Is my colleague in danger, am I in danger? (R22)

In the end, the police officer pulled his weapon.

If he is standing at a distance, I cannot... At that moment, the baton is useless, as also the pepper spray. If you pepper someone who is holding a gun, he can collapse because of the pain, but he can also get more aggressive and start to shoot at random. That is also not a solution. So the only thing you have left then is your own firearm. (R22)

The respondents agreed that the behaviour of the suspect is an important trigger for the use of force. They stated that the turning point towards force is different for each police officer and is in large part due to the character and personality of the police officer. Some police officers are very social-minded, so-called 'chatterers'. Those police officers can deal with a lot of situations and are very patient; they take their time and try to calm people by talking to them. Others, referred to as 'macho-types', however, have a shorter fuse and will resort to physical force more quickly.

There are colleagues with a shorter fuse, who are a little less patient. That I understand, but there are also colleagues who keep on chattering, and I'm not all for that, because when you keep chattering, they then will think that they can fool you around. At a certain moment, you have to be firm (R13)

Not all police officers are the same. There are also macho types who want to assert themselves (R22)

Respondents showed keen awareness of their own position in this respect, and stated that this will also be taken into consideration when choosing whom to team up with. In other words, someone who is more easily aggravated preferably will be combined with someone with a calmer personality. In this respect, self-knowledge is important. One police officer admitted that his verbal skills are not very good and that he can be quick-tempered. Therefore, he always works in second line, and his colleagues are aware of that.

The impact of partner choice is important in another respect as well. Some respondents stated that their reaction depends, among other things, on the reaction of their colleague; if a partner decides to use force, one must follow him or her along that scale. In this vein, one respondent stressed that in intervention work, it is important to work with fixed teams, so that, in time, one can anticipate one's partner's behaviour and try to deescalate the situation if necessary. By contrast, when working with varying teams, partners are more likely to support colleagues' out-of-scale behaviour, which can escalate a situation. 
Some of the respondents addressed police officers' tolerance (and intolerance) of verbal abuse. Although a certain tolerance level is expected from a police officer, this level varies among individuals. Remarkably, almost all police officers stated that they did not see verbal means of force used against them (such as insults) as real violence; rather, they considered it 'part of the job'. One police officer did not even react to a car thief, whom she had just arrested, spitting in her face:

Yes, because I am not a bantam, I just think, 'Okay then, let him be'. (R20)

Most of the respondents said of themselves that they would try to talk first when confronted with verbal abuse. Experience seems to be important in being able to assess the situation.

One of the police officers also emphasized the importance of body language and referred to the impact of the physical appearance of a police officer:

I am 1.90 m tall; with everything on I weigh 100 kilos. There are not many people who will say: yes, with that guy we will fight. (R17)

Another behavioural aspect affecting the application of force pertains to drunk or intoxicated suspects. People under the influence of drugs are often aggressive and present a risk to police officers, to any third parties and to the aggressor himself. In those cases, safety prevails and force will be used to prevent any harm to others. Respondents noted that people under the influence of drugs are often immune to the threat of police weapons, which implies that police officers must resort to immobilisation:

We are taught in police academy-and, as specialists in the control of violence, we also teach other police officers - specific techniques, but they do not work when used on people who are drunk or drugged. Alcohol lowers the threshold of pain, inhibitions disappear, also emotionally. Adrenaline also plays a role here. (RO3)

Interventions towards specific target groups can also pose problems. Mentally ill suspects or detainees call for specific attention and methods. Other cases that influence the reactions of police officers are those in which suspects are caught red-handed and dangerous situations in the public domain. Seven respondents gave examples of intervening in a fight. Three respondents (R2, R5 and R19) emphasized that, in the case of a fight, one should react immediately and in a firm and dominant way because-especially when there are more opponents than police officers-the chance exists that the fighting parties will turn against the police.

\section{Discussion}

As stated in the introduction, research on police use of force is predominantly conducted in AngloSaxon countries. In order to grasp the extent to which the results of these studies are applicable in continental European countries, this article attempts to gain insight into the Belgian situation by examining the use of force by Belgian police officers and what they report to be triggers for the use of force. To this end, quantitative data of an online survey amongst local police officers in three local police zones and interview data of 23 local police officers are combined. Although it has to be kept in mind that the two studies use different research methods, the authors believe the results are complementary in the sense that the interview data give more clarification to the statistics retrieved from the survey, as well as further insight into contextual triggers for the use of force. 
Certain limitations apply to both studies. First, both studies employed a convenience sample, which implicates a number of methodological limitations. Only local police officers (predominantly occupied with patrol work) were involved, without taking a random sample, meaning that the results cannot be generalised to cover all Belgian police officers. Second, although confidentiality was guaranteed, there may be bias in the results due to social desirability. However, despite these limitations, both studies contribute to the current knowledge on police use of force.

\subsection{Facts on police use of force}

In a recent overview of the state of knowledge on police use of force, Adams (2015) stipulates three 'facts' on police use of force that are known with substantial confidence, based on empirical research in the US: (1) police use of force occurs infrequently; (2) police use of force typically occurs at the lower end of the force continuum (including grabbing, pushing or shoving) and (3) use of force typically occurs when police are trying to make an arrest and the suspect is resisting. Let us consider these facts based on the findings of the present study, taking into account the limited generalisability.

Although the findings are difficult to interpret, as they cannot be compared to other reliable statistics and there is no contextual information available with regard to exposure and provocation, we can conclude that the officers in our sample rarely use force. When force is used, the type of force used is typically situated on the lower end of the continuum (verbal and physical force without a weapon). With regard to Adams' (2015) third statement, the interviews suggest that suspect resistance and the behaviour of the suspect in general (e.g., level of intoxication or mental health) have an influence on the use of force by police officers. The interviews suggest that the character and personality of the police officer in question also plays an important role. In addition, the data show that, in addition to arrest situations, the use of force often occurs in unpredictable situations in which no arrest is planned (e.g., traffic control). This is something future research should take into account. Future research in this field would also benefit from a more focused and in-depth approach in which respondents are asked about their strategies to avoid the use of force and their decision making processes in specific use-of-force situations.

\subsection{Triggers for the use of force}

As is supported by previous research, situational factors were mentioned as the main triggers for the use of force when opponents do not (or are not able to) react to warnings by the police, or when they are resistant; when there is an imminent danger to bystanders, the police officers or the person involved or when the opponent is armed (Klinger, 1994; Terrill and Mastrofski, 2002; Alpert and Dunham, 2004; Crawford and Burns, 2008; Waddington et al., 2009). Police officers quasiunanimously referred to the pyramid of force to justify their reactions in those situations. However, when a deadly weapon (e.g., a knife or a firearm) is directed towards them or other people, they will step immediately to the highest level of the scale. Of note is that one interviewee also pointed to the importance of the officer's physical appearance. This aspect is barely included in, or is omitted from, use-of-force continua used in previous research. Future research may take this into account. 
The turning point towards force seems to vary from person to person, depending on personal characteristics, level of training, years of experience and preferences for a certain weapon.

\subsection{Practical application of the results}

Our results imply that training should opt for a broad approach to the use of force, and make use of a variety of situations in training. Officers should be trained not only for situations of arrest, but also for unexpected changes in situations and to deal with intoxicated people. Furthermore, the results of the survey suggest that the training of police officers should predominantly focus on verbal and physical force, since those types of force are used most often, according to the respondents. Training on the use of the baton and pepper spray also seems important, as police officers deliberately decide not to use a certain weapon when they feel less trained in its use. In short, training is of the utmost importance.

In Belgium, operational police officers are obliged to attend at least five 4-hour training sessions annually on the use of force. Officers who are not exercising an operational function but are still carrying a firearm must attend only one training session a year [10]. It is clear that in only 20 hours a year it is not possible to train police officers intensively on the use of fighting techniques without a weapon as well as on the use of the different kinds of weapons. Therefore, more hours of required training, especially at the lower ends of the force continuum, are needed. It of course must be taken into account that the organization of training sessions is expensive and therefore less achievable for many local police zones, especially in the current economy. It may therefore be necessary to consider limiting the number of weapons police officers have at their disposal. Police officers can then focus on their skills in the use of these weapons. Only a few police officers have shot towards a target, yet all police officers carry a gun with only limited training on its proper use. In Norway, for instance, police officers are generally unarmed. Although there has been much discussion on the arms issue, the majority of Norwegian police officers do not want to be armed at all times, even given the terrorist attacks in Oslo and on the island of Utøya [11]. Knutsson and Strype's study (2003), which compared the use of firearms in Norway and Sweden, indicates that Norwegian police officers fire less than their Swedish counterparts, and that fewer officers and citizens are injured. These findings were explained by the more restrictive policy towards police use of firearms in Norway. In Belgium, however, as a result of the increased threat of terror following the terrorist attacks in Paris and Brussels, assistant police officers are recently allowed to to carry firearms [12], even though these officers have limited authority (e.g., traffic affairs and enforcement of police regulation).

\section{Conclusion}

Police use of force is an integral part of policing, and the fact that police can-and are expected touse force is one of the distinguishing elements of the police force in general. We expect our police to deal with problematic situations when they arise, hence we demand them to use force when necessary. This requires awareness that the use of force is not necessarily negative, and that the assumption that less force implies a better policeman or policewoman is not necessarily correct (Terrill, 2014). The use of force should be treated as a normal feature of police work, and police officers should be provided with training, coaching and aftercare as part of an effort to support the added responsibility that comes with the power to apply force. Increased transparency and reporting of the use and escalation of force would give us the basic information required to develop training, 
coaching and aftercare. After all, the use of force is both a limit on our democracy, and needed for the protection thereof. Thus it should be critically appraised.

\section{Acknowledgments}

A special thanks go out to the police officers who were willing to cooperate with both studies, and the students who carried out the interviews with them (Ann De Buck, Silke De Vogelaer, Juline Deseyne, Yinthe Feys, Kaat Goossens, Anja Hermans, Anne Koeleman, Fien Orbie, Daan Robbrecht, Ine Rotsaert, Yorick Standaert and Maartje van Poppel). The authors wish to expressly thank them for their efforts. The authors also would like to thank the Research Foundation of Flanders (FWO) and the anonymous reviewers whose suggestions and insights for our paper were invaluable.

\section{Bibliography}

Adams, K. (2015). What we know about police use of force. In R. G. Dunham \& G. P. Alpert (Eds.), Critical issues in policing: Contemporary Readings (7th ed.). Prospect Heights (III.) Waveland Press, Inc.

Alpert, G. P., \& Dunham, R. G. (2004). Understanding police use of force : officers, suspects, and reciprocity. Cambridge: Cambridge university press.

Alpert, G. P., Dunham, R. R., \& Mac Donald, J. M. (2004). Interactive police-citizen encounters that result in force. Police Quarterly, 7(4), 475-488.

Alpert, G. P., \& Mac Donald, J. M. (2001). Police use of force: An analysis of organisational characteristics. Justice Quarterly, 18(2), 393-409.

Bayley, D., \& Garofalo, J. (1989). The management of violence by police patrol officers. Criminology, 27, 1-27.

Bazley, T. D., Lersch, K. M., \& Mieczkowski, T. (2007). Officer force versus suspect resistance: A gendered analysis of patrol officers in an urban police department. Journal of Criminal Justice, 35(2), 183-192.

Binder, A., \& Scharf, P. (1980). The violent police-citizen encounter. Annals of the American Academy of Political and Social Science, 452, 111-121.

Birkbeck, C., \& Gabaldon, L. G. (1996). Avoiding complaints: Venezuelan police officers' situational criteria for the use of force against citizens. Policing and Society: An International Journal of Research and Policy, 6(2), 113-129.

Bittner, E. (1974). Florence Nightingale in pursuit of Willie Sutton: A theory of the police. In H. Jacob (Ed.), The potential for reform of criminal justice (pp. 352). Beverly Hills (Calif.) Sage.

Bittner, E. (1980). The functions of the police in modern society: a review of background factors, current practices, and possible role models. Cambridge (Mass.): Oelgeschlager Gunn and Hain.

Bourdoux, G., \& Cuvelier, C. (2007). Leren uit geweldsincidenten. In F. Hutsebaut (Ed.), Politie en het gebruik van geweld (Vol. Cahiers Politiestudies $n^{\circ} 5$, pp. 47-69). Brussel: Politeia.

Cancino, J. M. (2001). Walking among giants 50 years later. An exploratory analysis of patrol officer use of violence. Policing: An International Journal of Police Strategies \& Management, 24(2), 144-161.

Chan, J. (1996). Changing Police Culture. British Journal of Criminology, 36(1), 109-134.

Cook, P. J., Braga, A. A., \& Moore, M. H. (2011). Gun Control. Crime and Public Policy, 257-292.

Crawford, C., \& Burns, R. (2008). Police use of force: assessing the impact of time and space. Policing \& Society, 18(3), 322-335. 
Dejonghe, N. (2009). Cursus Geweldsbeheersing. Basisopleiding aspirant-inspecteurs. Ghent: OPAC.

Dick, P. (2005). Dirty work designations: How police officers account for their use of coercive force. Human Relations, 58(11), 1363-1390.

Engel, R., Sobol, J. J., \& Worden, R. E. (2000). Further exploration of the demeanor hypothesis: The interaction of suspects' characteristics and demeanor on police behavior. Justice Quarterly, $17,235-258$.

Eysenck, M. W., Derakshan, N., Santos, R., \& Calvo, M. G. (2007). Anxiety and cognitive performance: attentional control theory. Emotion, 7(2), 336-353.

Garner, J., Buchanan, J., Schade, T., \& Hepburn, J. (1996). Understanding the use of force by and against the police. Washington D.C.: National Institute of Justice Research.

Garner, J., Schade, T., Hepburn, J., \& Buchanan, J. (1995). Measuring the continuum of force used by and against the police. Criminal Justice Review, 20, 146-168.

Goossens, F. (2006). Politiebevoegdheden en mensenrechten. Mechelen: Kluwer.

Goossens, F., \& Hutsebaut, F. (2007). Politioneel geweld- en vuurwapengebruik in België: het nationale wettelijke kader. In F. Hutsebaut (Ed.), Politie en het gebruik van geweld (Vol. Cahiers Politiestudies n5, pp. 47-69). Brussel: Politeia

Grossman, D., \& Christensen, L. W. (2004). On combat: The psychology and physiology of deadly conflict in war and peace. Millstadt: PPCT Research publications

Herbert, S. (1998). Police Subculture Reconsidered. Criminology, 36(2), 343-370.

Holmes, S. T., Reynolds, K. M., Holmes, R. M., \& Faulkner, S. (1998). Individual and situational determinants of police force: an examination of threat presentation. American Journal of Criminal Justice, 23(1), 83-106.

Jones, T., Newburn, T., \& Smith, D. J. (1996). Policing and the idea of democracy. British Journal of Criminology, 36(2), 182-198.

Klinger, D. A. (1994). Demeanor or crime? Why "hostile" citizens are more likely to be arrested. Criminology, 32(3), 475-493.

Klinger, D. A. (2006). Police responses to officer-involved shootings. National Institute of Justice Journal, 253, 21.

Klinger, D. A., \& Brunson, R. K. (2009). Police officers' perceptual distortions during lethal force situations: informing the reasonableness standard. Criminology \& Public Policy, 8(1), 117140.

Knutsson, J., \& Strype, J. (2003). Police use of firearms in Norway and Sweden: The significance of gun availability. Policing and Society, 13(4), 429-439.

Kop, N., \& Euwema, M. C. (2001). Occupational stress and the use of force by Dutch police officers. Criminal Justice and Behavior, 28(5), 631-652.

Liedtka, J. M. (1992). Exploring ethical issues using personal interviews. Business Ethics Quarterly, 2(2), 161-181.

Manzoni, P., \& Eisner, M. (2006). Violence between the police and the public: influences of workrelated stress, job satisfaction, burnout and situational factors. Crime Law and Social Change, $52,181-206$.

Morabito, E. G., \& Doerner, W. G. (1997). Police use of less-than-lethal force: Oleoresin Capsicum (OC) spray. Policing: An International Journal of Police Strategies \& Management, 20(4), 680697.

Nieuwenhuys, A., \& Oudejans, R. R. D. (2010). Effects of anxiety on handgun shooting behavior of police officers: a pilot study. Anxiety Stress and Coping, 23(2), 225-233.

Noppe, J. (2015). Studying police use of force: definitional challenges \& methodological considerations. In C. da Agra, C. Cardoso, J. de Maillard, C. O'Reily, J. Shapland \& P. Ponsaers (Eds.), Criminology, Security and Justice: methodological and epistemological issues (Vol. 3, pp. 105-132). Antwerpen: Maklu.

Novy, M. (2012). Cognitive distortions during law enforcement shootings. Activitas Nervosa Superior, $54,1-2$ 
Paoline, E. A. (2003). Taking stock: Toward a richer understanding of police culture. Journal of Criminal Justice, 31, 199-214.

Paoline, E. A., \& Terrill, W. (2007). Police education, experience and the use of force. Criminal justice and Behavior, 34(2), 179-196.

Roberts, A. P., \& Cole, J. C. (2013). The effects of exercise and body armor on cognitive function in healthy volunteers. Military medicine, 178(5), 479-486

Shipley, P., \& Baranski, J. V. (2002). Police officer performance under stress: A pilot study on the effects of visuo-motor behavior rehearsal. International Journal of Stress Management, 9(2), 71-80.

Siddle, B. K. (1995). Sharpening the warrior's edge: the psychology \& science of training. Millstadt, IL: PPCT Management Systems.

Stenning, P., Birkbeck, C., Adang, O., Baker, D., Feltes, T., Gabaldon, L. G., . . W Waddington, P. A. J. (2009). Researching the use of force: the background to the international project. Crime, Law and Social Change, 52(2), 95-110.

Taverniers, J., Smeets, T., Van Ruysseveldt, J., Syroit, J., \& von Grumbkow, J. (2011). The risk of being shot at: stress, cortisol secretion and their impact on memory and perceived learning during reality-based practice of armed officers. International Journal of Stress Management, 18(2), 113-132. doi: 10.1037/a0023742

Terrill, W. (2001). Police coercion: Application of the force continuum. Rutgers State University of New Jersey, Newark.

Terrill, W. (2014). Police Coercion. In M. D. Reisig \& R. J. Kane (Eds.), The Oxford Handbook of Police and Policing (pp. 260-279). New York: Oxford University Press.

Terrill, W., \& Mastrofski, S. (2002). Situational and officer-based determinants of police coercion. Justice Quarterly, 19(2), 215-248.

Terrill, W., Paoline, E. A., \& Manning, P. K. (2003). Police culture and coercion. Criminology, 41(4), 1003-1034.

Terrill, W., \& Reisig, M. D. (2003). Neighborhood context and police use of force. Journal of Research in Crime and Delinquency, 40(3), 291-321.

Timmer, J. (2005). Politiegeweld. Geweldgebruik van en tegen de politie in Nederland. Alphen aan den Rijn: Kluwer.

Uildriks, N. A. (1997). De normering en beheersing van politiegeweld. Arnhem: Gouda Quint.

Van Maanen, J. (1974). Working the street: A developmental view of police behavior. In J. Herbert (Ed.), The Potential for Reform of Criminal Justice (Vol. 3, pp. 83-130). Beverly Hills (California): Sage.

van Staa, A. L., \& Evers, J. (2010). 'Thick analysis': strategie om de kwaliteit van kwalitatieve dataanalyse te verhogen. KWALON. Tijdschrift voor Kwalitatief Onderzoek in Nederland, 43(1), 512.

Vonck, K. D. (2007). Police Performance Under Stress. Law \& Order, 56(10), 86-92.

Waddington, P. A. J., Adang, O., Baker, D., Birkbeck, C., Feltes, T., Gabaldón, L. G., ... \& Stenning, P. (2009). Singing the same tune? International continuities and discontinuities in how police talk about using force. Crime, Law and Social Change, 52(2), 111-138.

Weston, C., Gandell, T., Beauchamp, J., McAlpine, L., Wiseman, C., \& Beauchamp, C. (2001). Analyzing interview data: The development and evolution of a coding system. Qualitative sociology, 24(3), 381-400.

Wolf, R., Mesloh, C., Henych, M., \& Thompson, F. (2009). Police use of force and the cumulative force factor. Policing, 32(4), 739-757.

Worden, R. E. (1996). The Causes of Police Brutality: Theory and Evidence on Police Use of Force. In W. A. Geller \& H. Toch (Eds.), Police Violence: Understanding and controlling police abuse of force (pp. 23-51). New Haven (Conn.): Yale University. 


\section{Notes}

[1] In Belgium, there is strict legislation with regard to the possession of arms. The possession of firearms is prohibited, except for a category of particular firearms for which one needs to apply for a licence (e.g. sporting-guns and collector's items).

[2] Politiet. Politidirektoratet (2015). Politiets trussel om bruk av skytevåpen eller bruk av skytevåpen 2002-2014. (Police threat with or use of firearms 2002-2014) Statistikknotat oppdatert 1. Juni 2015, $\begin{array}{lllll}\text { avdeling for og politiberedskap } & \text { URL: }\end{array}$ https://www.politi.no/vedlegg/lokale vedlegg/politidirektoratet/Vedlegg 3021.pdf

[3] For about two years, the federal police have been working on a uniform reporting form for reporting every use of force (as prescribed by the GPI 62), but due to several pragmatic reasons, the implementation of the system will be delayed.

[4] In accordance with the typology used for the Belgian 'veiligheidsmonitor' (safety monitor): big cities (type 1); regional cities or municipalities of Brussel-18 (type 2); agglomerations/conurbations and well-equipped small cities (type 3); moderate or less-equipped small cities or strongly morphological, urbanized municipalities (type 4) and moderate or weak morphological, urbanized municipalities (type 5). We chose urban settings to fulfil the need for a certain degree of variety in use of force, in order to conduct inferential analyses. In this article, however, only descriptive results are presented.

[5] The first police zone consists of 379 operational police officers, the second comprises 242 operational police officers and the third consists of 260 operational police officers.

[6] The students were prepared intensively during several classes. In total, 12 students carried out 24 interviews in the spring of 2014.

[7] 'Intervention teams' and 'intervention work' refer to the work of police officers who are the first at the scene to intervene after a call to the police.

[8] Students were asked to interview a police officer working for the intervention team in his or her place of residence. This resulted in 24 interviews, of which 23 interviews were determined by careful analysis to be useful for this paper. One of the interviews concerned a Dutch police officer, which we decided to exclude from our sample due to differences in context and legal frameworks.

[9] This is a suicide method in which a suicidal individual deliberately acts in a threatening way, provoking a lethal response from a law enforcement officer or another legitimately armed individual.

[10] Circular GPI 48 concerning the education and training on the use of force for operational police officers, B.S., March 17, 2006.

[11] http://www.newsinenglish.no/2011/10/13/police-dont-want-to-bear-arms/

[12] Assistant officers in Belgium only have limited authority. They are mainly occupied with traffic affairs and enforcement of police regulation. 